\title{
Nine-year prospective efficacy and safety of brain- responsive neurostimulation for focal epilepsy
}

Dileep R. Nair, MD, Kenneth D. Laxer, MD, Peter B. Weber, MD, Anthony M. Murro, MD, Yong D. Park, MD, Gregory L. Barkley, MD, Brien J. Smith, MD, Ryder P. Gwinn, MD, Michael J. Doherty, MD,

Katherine H. Noe, MD, PhD, Richard S. Zimmerman, MD, Gregory K. Bergey, MD, William S. Anderson, MD, PhD, Christianne Heck, MD, Charles Y. Liu, MD, PhD, Ricky W. Lee, MD, Toni Sadler, PA-C, Robert B. Duckrow, MD, Lawrence J. Hirsch, MD, Robert E. Wharen, Jr., MD, William Tatum, DO, Shraddha Srinivasan, MD, Guy M. McKhann, MD, Mark A. Agostini, MD, Andreas V. Alexopoulos, MD, MPH, Barbara C. Jobst, MD, David W. Roberts, MD, Vicenta Salanova, MD, Thomas C. Witt, MD, Sydney S. Cash, MD, PhD, Andrew J. Cole, MD, Gregory A. Worrell, MD, PhD, Brian N. Lundstrom, MD, PhD, Jonathan C. Edwards, MD, Jonathan J. Halford, MD, David C. Spencer, MD, Lia Ernst, MD, Christopher T. Skidmore, MD, Michael R. Sperling, MD, lan Miller, MD, Eric B. Geller, MD, Michel J. Berg, MD, A. James Fessler, MD, Paul Rutecki, MD, Alica M. Goldman, MD, PhD, Eli M. Mizrahi, MD, Robert E. Gross, MD, PhD, Donald C. Shields, MD, Theodore H. Schwartz, MD, Douglas R. Labar, MD, PhD, Nathan B. Fountain, MD, W. Jeff Elias, MD, Piotr W. Olejniczak, MD, PhD, Nicole R. Villemarette-Pittman, PhD, Stephan Eisenschenk, MD, Steven N. Roper, MD, Jane G. Boggs, MD, Tracy A. Courtney, BS, Felice T. Sun, PhD, Cairn G. Seale, MS, Kathy L. Miller, BS, Tara L. Skarpaas, PhD, and Martha J. Morrell, MD, on behalf of the RNS System LTT Study

Neurology ${ }^{\circledR}$ 2020;95:e1244-e1256. doi:10.1212/WNL.0000000000010154

\section{Abstract Objective}

To prospectively evaluate safety and efficacy of brain-responsive neurostimulation in adults with medically intractable focal onset seizures (FOS) over 9 years.

\section{Methods}

Adults treated with brain-responsive neurostimulation in 2-year feasibility or randomized controlled trials were enrolled in a long-term prospective open label trial (LTT) to assess safety, efficacy, and quality of life (QOL) over an additional 7 years. Safety was assessed as adverse events (AEs), efficacy as median percent change in seizure frequency and responder rate, and QOL with the Quality of Life in Epilepsy (QOLIE-89) inventory.

\section{Results}

Of 256 patients treated in the initial trials, 230 participated in the LTT. At 9 years, the median percent reduction in seizure frequency was $75 \%(p<0.0001$, Wilcoxon signed rank), responder rate was $73 \%$, and $35 \%$ had a $\geq 90 \%$ reduction in seizure frequency. We found that $18.4 \%$ (47 of 256) experienced $\geq 1$ year of seizure freedom, with $62 \%$ (29 of 47) seizure-free at the last follow-up and an average seizure-free period of 3.2 years (range 1.04-9.6 years). Overall QOL and epilepsytargeted and cognitive domains of QOLIE- 89 remained significantly improved $(p<0.05)$. There were no serious AEs related to stimulation, and the sudden unexplained death in epilepsy (SUDEP) rate was significantly lower than predefined comparators $\left(p<0.05,1\right.$-tailed $\left.\chi^{2}\right)$.

\author{
Correspondence \\ Dr. Morrell \\ mmorrell@neuropace.com
}

MORE ONLINE

$\rightarrow$ Class of Evidence

Criteria for rating therapeutic and diagnostic studies

NPub.org/coe

\section{ค Podcast}

Dr. Halley Alexander and

Dr. Martha Morrell talk

about Dr. Morrell's paper on neurostimulation in focal epilepsy.

NPub.org/rud9e4

\section{- CME Course}

NPub.org/cmelist

From the Cleveland Clinic Foundation (D.R.N., A.V.A.), OH; California Pacific Medical Center (K.D.L., P.B.W.), San Francisco; Augusta University (A.M.M., Y.D.P.), GA; Henry Ford Hospital (G.L.B.), Detroit, MI; Ohio Health Neuroscience (B.J.S.), Columbus; Swedish Neuroscience Institute (R.P.G., M.J.D.), Seattle, WA; Mayo Clinic Arizona (K.H.N., R.S.Z.), Scottsdale; Johns Hopkins Medicine (G.K.B., W.S.A.), Baltimore, MD; Keck School of Medicine of USC (C.H., C.Y.L.), Los Angeles, CA; Via Christi Epilepsy Center (R.W.L., T.S.), Wichita, KS; Yale University School of Medicine (R.B.D., L.J.H.), New Haven, CT; Mayo Clinic Florida (R.E.W., W.T.), Jacksonville; Columbia University Medical Center (S.S., G.M.M.), New York, NY; University of Texas Southwestern Medical Center (M.A.A.), Dallas; Geisel School of Medicine at Dartmouth (B.C.J., D.W.R.), Hanover, NH; Indiana University School of Medicine (V.S., T.C.W.), Indianapolis; Massachusetts General Hospital (S.S.C., A.J.C.), Boston; Mayo Clinic Minnesota (G.A.W., B.N.L.), Rochester; Medical University of South Carolina (I.C.E., J.J.H.), Charleston; Oregon Health \& Science University (D.C. Spencer, L.E.), Portland; Thomas Jefferson University (C.T.S., M.R.S.), Philadelphia, PA; Nicklaus Children's Hospital (I.M.), Miami, FL; Saint Barnabas Medical Center (E.B.G.), Livingston, NJ; University of Rochester Medical Center (M.J.B., A.J.F.), NY; University of Wisconsin Hospital and Clinics (P.R.), Madison; Baylor College of Medicine (A.M.G., E.M.M.), Houston, TX; Emory University School of Medicine (R.E.G.), Atlanta, GA; George Washington University School of Medicine and Health Sciences (D.C. Shields), Washington, DC; Weill Cornell Medical College (T.H.S., D.R.L.), New York, NY; University of Virginia School of Medicine (N.B.F., W.J.E.), Charlottesville; Louisiana State University Health Sciences Center (P.W.O., N.R.V.-P.), New Orleans; University of Florida (S.E., S.N.R.), Gainesville; Wake Forest University Health Sciences (J.G.B.), Winston-Salem, NC; NeuroPace, Inc (T.A.C., F.T.S., C.G.S., K.L.M., T.L.S., M.J.M.), Mountain View; and Stanford University (M.J.M.), Palo Alto, CA.

Go to Neurology.org/N for full disclosures. Funding information and disclosures deemed relevant by the authors, if any, are provided at the end of the article. 


\section{Glossary}

$\mathbf{A E}=$ adverse event $\mathbf{C I}=$ confidence interval; $\mathbf{D B S}=$ deep brain stimulation; $\mathbf{E C o G}=$ electrocorticographic; FDA = Food and Drug Administration; GEE = generalized estimating equation; $I Q R=$ interquartile range; LOCF = last observation carried forward; LTT = long-term treatment; QOL = quality of life; QOLIE-89 = Quality of Life in Epilepsy; SAE = serious AE; SUDEP = sudden unexplained death in epilepsy; VNS = vagus nerve stimulation.

\section{Conclusions}

Adjunctive brain-responsive neurostimulation provides significant and sustained reductions in the frequency of FOS with improved QOL. Stimulation was well tolerated; implantation-related AEs were typical of other neurostimulation devices; and SUDEP rates were low.

\section{ClinicalTrials.gov identifier}

NCT00572195.

\section{Classification of evidence}

This study provides Class IV evidence that brain-responsive neurostimulation significantly reduces focal seizures with acceptable safety over 9 years.

About $30 \%$ to $40 \%$ of patients with epilepsy are refractory to medications. While resective or ablative procedures provide the best likelihood of seizure freedom, ${ }^{1-3}$ these approaches are not an option for many patients due to the potential for neurologic risk or insufficient likelihood of benefit. Neuromodulation approaches, including vagus nerve stimulation ${ }^{4,5}$ (VNS), deep brain stimulation ${ }^{6,7}$ (DBS), and brain-responsive neurostimulation ${ }^{8-10}$ (RNS System, NeuroPace, Inc), have been demonstrated to be safe and effective treatments to reduce seizure frequency for these patients. In contrast to DBS, brain-responsive neurostimulation delivers stimulation only in response to changes in ongoing neural activity at the seizure focus. ${ }^{8-10}$ While this approach requires the identification of the seizure focus, it limits the amount of stimulation delivered per day. $^{8-10}$

The RNS System is approved by the US Food and Drug Administration (FDA) as an adjunctive treatment for adults with medically refractory focal onset seizures arising from 1 or 2 seizure foci. $^{8-10}$ An initial 2-year feasibility study $(n=65)$ demonstrated safety and provided preliminary evidence of effectiveness, and a 2-year double-blinded randomized controlled trial $(n=191)$ demonstrated safety and effectiveness. Final results are provided from an FDA-requested and -approved prospective open-label long-term treatment (LTT) clinical study intended to collect an additional 7 years of prospective data on the safety and effectiveness of the RNS System. This report of 9 years of patient follow-up supplements and extends the experience and observations presented in an interim analysis ${ }^{8}$ and represents the largest multicenter prospective trial in the field of neuromodulation to date.

\section{Methods}

The RNS System (NeuroPace, Inc, Mountain View, CA) provides brain-responsive (closed-loop) neurostimulation when abnormal electrocorticographic (ECoG) activity is detected, typically epileptiform activity that is observed at the onset of electrographic seizures. As described in a prior publication, ${ }^{11}$ a cranially implanted programmable neurostimulator is connected to depth or subdural cortical strip leads that are placed according to the patient's previously identified seizure focus or foci. Each lead contains 4 electrode contacts (figure 1). Two leads can be connected to the neurostimulator at a time, and as many as 4 leads could be implanted in the clinical trials (no more than 2 depth leads). The neurostimulator continually senses ECoG activity through the electrodes and is programmed by the physician to detect specific ECoG patterns and to deliver stimulus pulses in response to detections. The physician adjusts detection and stimulation parameters for each patient as needed for seizure reduction. ${ }^{8}$

The LTT study was open to patients who participated in the 2-year feasibility or pivotal studies beginning in 2004 and completed in 2018. Patients were followed up for an additional 7 years. Adverse event (AE) and daily seizure diary data were collected every 6 months at a minimum. Quality of life (QOL) was assessed yearly by the Quality of Life in Epilepsy (QOLIE-89). ${ }^{12}$ Safety was assessed as spontaneously reported AEs, which were categorized by the investigator as mild or serious and as device related, of uncertain device relation, or not device related. An independent data monitoring committee reviewed all AEs. All deaths were also evaluated by a sudden unexplained death in epilepsy (SUDEP) analysis committee that adjudicated whether the death was possibly, probably, or definitely related to SUDEP or not SUDEP.

Efficacy was assessed as median percent change in seizure frequency and as responder rate (the percentage of patients with a $\geq 50 \%$ reduction in seizure frequency) for each 6-month 


\section{Figure 1 RNS System}
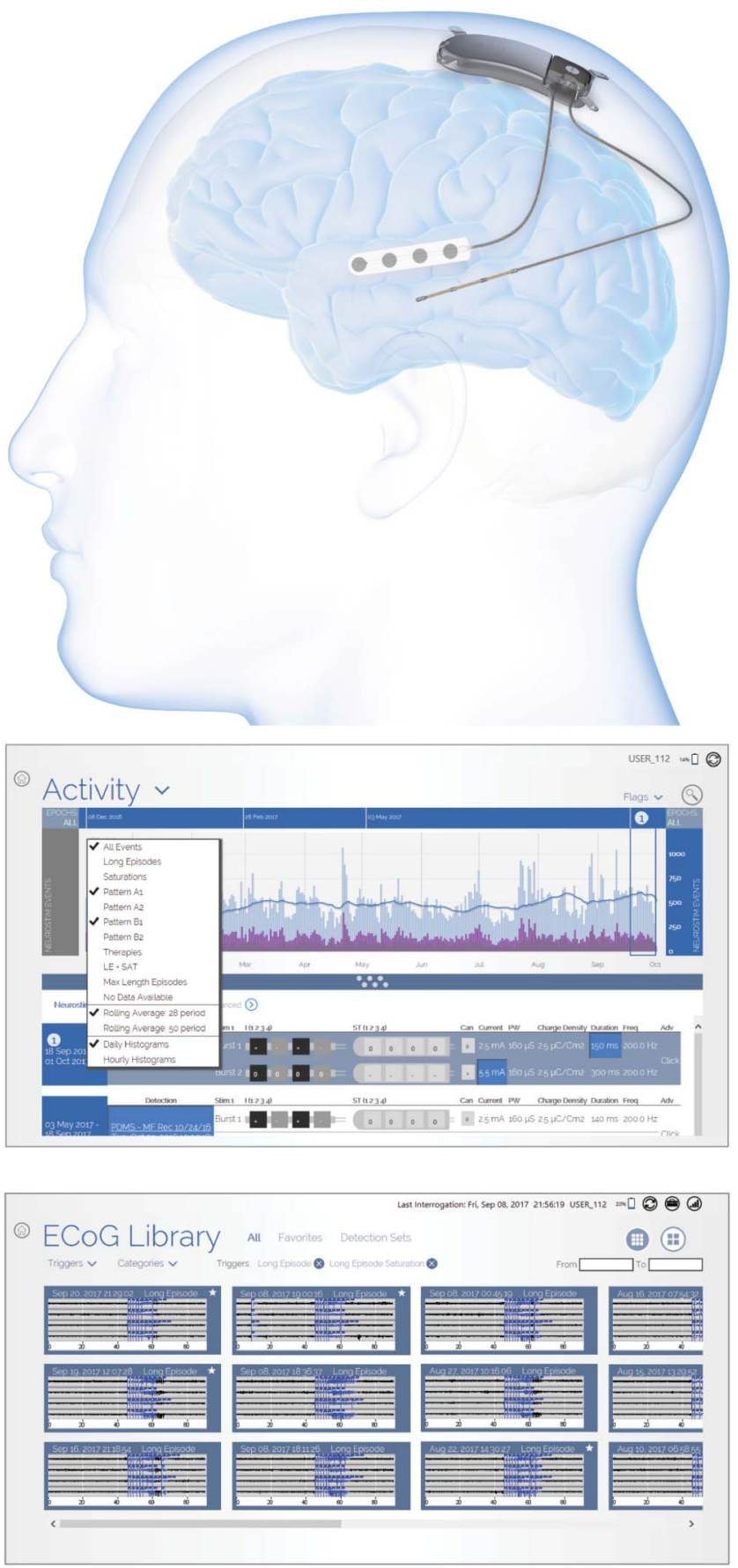

Left, RNS neurostimulator and NeuroPace cortical strip and depth leads. Top right, record of the number of electrographic events detected by the neurostimulator over time for an individual patient. Bottom right, snapshots of electrographic activity recorded by the RNS System for an individual patient. Copyright (c) 2020 NeuroPace, Inc.

period compared to the prospective preimplantation baseline for patients with a minimum diary requirement of 91 recorded days per 182-day period ( $\geq 91$ days diary requirement). The significance of the reduction in seizure frequency at each time point was assessed with the Wilcoxon signed rank test $(\alpha<$ $0.05)$. The robustness of the efficacy outcome was tested with several different analysis approaches, including a constant cohort (data at each time point from all patients who completed the trial) analysis and a last observation carried forward (LOCF) analysis. If improvements in seizure frequency over time were driven primarily by patient dropout, then the median percent reduction for the constant cohort, LOCF populations, or both would be expected to remain similar at all time points.

To test whether there was continued improvement in seizure frequency over time, the percent change in seizure frequency for each 6-month period was modeled with a generalized estimating equation (GEE) model with time (defined as $0,1,2,3$... for each consecutive 6-month period beginning with months 6-12 as the first period). For each participant, only periods with at least 91 of 182 days of seizure diary data were included; the remaining periods were considered missing data. The GEE model used a compound symmetry correlation structure to account for repeated measurements per participant over the course of the study. In this model, the estimated value of the intercept was interpreted as the estimated percent change in the first 6-month period (months 6-12). The estimated value of the slope was then interpreted as the estimated linear change in the percent change in seizure frequency over the remaining periods $(\alpha<$ 0.05 ). Additional GEE models were performed on subgroups to assess whether clinical covariates such as age at enrollment (by median split), age at onset (by median split), prior surgery for epilepsy (yes/no), prior intracranial monitoring (yes/no), prior VNS (yes/no), abnormality on brain MRI (yes/no), number of seizure onset zones (1/2), and seizure onset location (mesial temporal lobe/neocortical/both) were predictive of outcome.

Antiseizure medications could be adjusted as medically necessary. The impact of changing antiseizure medications on the clinical outcomes at the last follow-up was compared to baseline. An increase in antiseizure medications was defined as a $\geq 25 \%$ increase in dose, the addition of a medication not taken at baseline, or both. A decrease was defined as a $\geq 25 \%$ reduction in dose, the discontinuation of an antiseizure medication, or both. Patients in the mixed category had both a qualifying increase in $\geq 1$ medications and a qualifying decrease in $\geq 1$ medications. Patients in the no change category were on the same medications and doses $( \pm<25 \%)$ at the last follow-up as at baseline. The reduction in clinical seizure frequency during the last 6 months of follow-up using the LOCF population was then compared between the patients in the 4 groups (increase, decrease, mixed, or no change) with the Wilcoxon rank sum tests $(\alpha<0.05)$.

Average changes in the QOLIE-89 overall $\mathrm{T}$ score and 4 subdomains of QOL were compared to the preimplantation baseline with a paired $t$ test.

\section{Neurostimulator battery longevity}

A Kaplan-Meier survival analysis was used to estimate the median survival of the RNS-300M (the neurostimulator model primarily used in the LTT study). The analysis included all RNS-300M devices implanted through April 2019 and excluded devices explanted for reasons other than battery depletion (e.g., infection or lead revision). 


\section{Standard protocol approvals, registrations, and patient consents}

All study protocols were approved by the FDA and the institutional review boards of the participating investigation sites. All participants gave written informed consent. The LTT study is registered on clinicaltrials.gov (NCT00572195).

\section{Classification of evidence}

This prospective open-label study provides Class IV evidence that brain-responsive neurostimulation is acceptably safe, reduces seizure frequency, and improves QOL in adults with medically refractory focal onset seizures over a mean followup of 7.5 years (range 5 weeks-11.2 years; median follow-up 8.97 years). One hundred seventy-three of the participants were part of the original randomized double-blinded trial that provided Class I evidence for safety and effectiveness.

\section{Data availability}

No data are available.

\section{Results}

Two hundred fifty-six participants were initially implanted with the RNS Neurostimulator and NeuroPace leads within the feasibility and pivotal studies combined; 230 enrolled in the LTT study, and 162 completed all 9 years of follow-up. This provides an accumulated experience of 1,895 patientimplantation years and 1,788 years over which brainresponsive neurostimulation was enabled. The mean followup period was 7.5 years (SD 2.9 years, range 5 weeks-11.2 years), and the median follow-up was 8.97 years. Subject accountability is provided in figure 2.

Subject demographics and clinical characteristics for all implanted participants are provided in table 1. The participants had experienced frequent seizures (mean \pm SD seizure frequency per month $50.7 \pm 177.4$ ) for many years (mean \pm SD duration of epilepsy $19.7 \pm 11.4$ years). One-third had been treated with VNS and one-third with epilepsy surgery.

\section{Efficacy}

\section{Device settings}

Over the 9 years of follow-up, patients received an average of 1,028 detections per day (range 5-3,091). The most common stimulation therapy settings were 2 bursts of stimulation at 100 to $200 \mathrm{~Hz}, 160$-microsecond pulse width, and 100-millisecond burst duration with the majority of detections resulting in the delivery of a single therapy. Thus, for this cohort, the maximum amount of stimulation delivered per day was 10.3 minutes with patients receiving on average 3.4 minutes of stimulation per day.

\section{Seizure reduction}

Seizure reductions in 6 months intervals were statistically significant over the entire 9 years of follow-up compared to baseline. Figure $3 \mathrm{~A}$ shows the median seizure frequency change from baseline during the LTT study (3-9 years after implantation). The reduction in seizures is displayed for the population who met the 91-day minimum diary requirement, a constant cohort, and an LOCF population. The reduction in seizures improved over the additional 7 years of follow-up. Based on the 91-day minimum diary requirement population, the median percent reduction at the end of year 3 was $58 \%$. This improved steadily, reaching $75 \%$ by the end of 9 years of treatment $(p<0.0001$, Wilcoxon signed rank). Similar results were observed with the other analysis approaches, suggesting that the improvement over time was not due to enrichment in the patient population (figure 3A). In the 91day seizure diary requirement population, the GEE estimated a statistically significant continued reduction in seizures of $1.2 \%$ per 6-month period over time $(p<0.001)$. Figure 3B shows the distribution of individual responses to treatment at 9 years for participants with at least 91 days of seizure diary data; the responder rate was $73 \%$; $35 \%$ had a $\geq 90 \%$ reduction in their seizures; and $21 \%$ were seizure-free in the last 6 months of follow-up.

\section{Seizure reductions and clinical covariates}

The slope of the median percent reduction in seizure frequency over time was not influenced by any of the clinical covariates. The improvement in the median percent reduction in seizure frequency was similar for participants with and without prior epilepsy surgery $(p=0.33)$, VNS $(p=0.70)$, or intracranial monitoring $(p=0.39)$. In addition, the reduction in seizure frequency over time was not influenced by the participant's age at enrollment $(p=0.26)$, age at seizure onset $(p=0.24)$, the presence or absence of any brain abnormality on imaging $(p=0.51)$, the seizure onset location $(p=0.34)$, or the number of seizure foci $(p=0.20)$.

Figure 2 RNS System studies, participant accountability

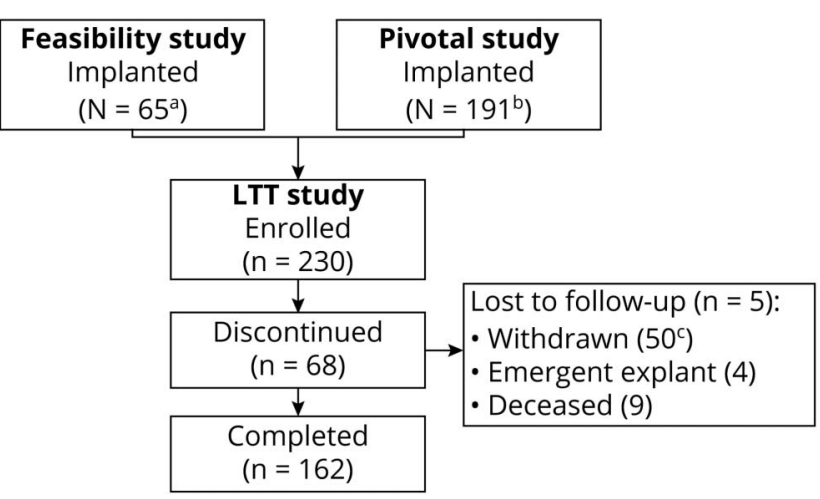

${ }^{a}$ Feasibility study: 6 participants discontinued before completing the study; 2 participants completed the study but elected not to enroll in the long-term treatment (LTT) study. Thus, 57 participants in the feasibility study enrolled

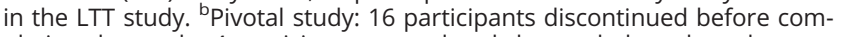
pleting the study; 4 participants completed the study but elected not to enroll in the LTT study. Two participants who discontinued early were granted waivers and were allowed to enroll, resulting in 173 pivotal participants enrolling into LTT. A total of 230 participants chose to enroll in the LTT study, and 162 participants completed the study. 'Reasons for early withdrawal from the LTT study included the following: chose not to replace neurostimulator $(n=20)$; to pursue other treatment options $(n=10)$; insufficient efficacy $(n=8)$; study noncompliance $(n=7)$; and to receive medical care at a nonstudy center $(n=5)$. 
Table 1 Demographics and characteristics of all participants with implantations $(n=256)$

\begin{tabular}{|c|c|}
\hline Female, \% (n) & $49(125 / 256)$ \\
\hline Age, $^{\text {a }}$ mean \pm SD (range), y & $\begin{array}{l}34.0 \pm 11.3 \\
(18-66)\end{array}$ \\
\hline Duration of epilepsy, ${ }^{a}$ mean \pm SD (range), $y$ & $\begin{array}{l}19.7 \pm 11.4 \\
(2-58)\end{array}$ \\
\hline $\mathrm{AEDs}{ }^{\mathrm{a}}$ mean $\pm \mathrm{SD}$ (range), $n$ & $2.9 \pm 1.1(0-8)$ \\
\hline $\begin{array}{l}\text { Preimplantation disabling seizures per month, mean } \\
\pm \text { SD (median), } \mathrm{n}\end{array}$ & $\begin{array}{l}50.7 \pm 177.4 \\
(10.2)\end{array}$ \\
\hline Prior intracranial monitoring, \% (n) & $65(166 / 256)$ \\
\hline Prior epilepsy surgery, \% (n) & $34(86 / 256)$ \\
\hline Prior VNS, \% (n) & $32(82 / 256)$ \\
\hline Two seizure foci (vs one), \% (n) & $48(124 / 256)$ \\
\hline Mesial temporal lobe only onsets (vs other), \% (n) & $43(111 / 256)$ \\
\hline
\end{tabular}

Abbreviation: AED = antiepileptic drug; VNS = vagus nerve stimulation. a At enrollment in initial study (feasibility or pivotal).

Copyright (c) 2020 NeuroPace, Inc.

\section{Seizure reductions and antiseizure medications}

Antiseizure medications were adjusted in many patients over the open-label follow-up, as was allowed in the protocol (table 2 ). There were no statistically significant differences in the efficacy endpoints at last follow-up between patients who had an addition or increase in antiseizure medications, patients who had a decrease, and those who had no change $(p>0.05)$.

\section{Seizure reductions and lobe of seizure onset}

In addition, median percent seizure reductions at 9 years were similar for participants with seizure onsets in the mesial temporal lobe, unilateral or bilateral (73\%; interquartile range [IQR] $58 \%-96 \%$; $n=66)$, or in the neocortex ( $81 \%$; IQR $34 \%-100 \%$; $\mathrm{n}=70$ ), including frontal lobe (93\%; IQR $31 \%-100 \% ; \mathrm{n}=21)$, and other regions of the neocortex (79\%; IQR 52\%-93\%; $n=$ 30 ). Seizure reductions for each onset region are provided in table 3.

\section{Seizure freedom}

Over the 9 years of follow-up, many patients experienced prolonged seizure-free periods (figure 3C); $28.1 \%$ (72 of 256) had at least 1 seizure-free period of $\geq 6$ months, while $18.4 \%$ ( 47 of 256 ) had at least 1 seizure-free period of $\geq 1$ year. For patients with at least 1 year of seizure freedom, the average duration of their longest consecutive period of seizure-free days was 3.2 years (range $1.04-9.6$ years). At the completion of the study, $62 \%$ (29 of 47) of patients with $\geq 1$ year of seizure freedom were also seizure-free during the last year of follow-up.

\section{Quality of life}

Overall QOLIE-89 scores improved at 1 year $(\mathrm{n}=212$, mean 3.2, SD 8.6, $p<0.0001$ ), and improvements were maintained through year 9 of treatment $(\mathrm{n}=145$, mean 1.9, SD 11.1, $p<0.05$ ), as were statistically significant improvements in epilepsy targeted $(\mathrm{n}=145$, mean 4.5 , SD 10.4, $p<0.001)$ and cognitive $(\mathrm{n}=145$, mean 2.5 , SD 10.5, $p=0.005)$ domains.

\section{Safety}

\section{Device-related serious AEs}

Over the entire follow-up, the only device-related serious AEs (SAEs) that were reported in $\geq 5 \%$ of patients cumulatively were implantation site infection and elective explantation of the neurostimulator, leads, or both. The risk of infection per procedure (initial implantation, replacement, or revision) was $4.1 \%$. Over the cumulative 1,895 patient-implantation years, serious device-related implantation site infection was reported in $12.1 \%$ of participants. The events were typically reported shortly after a surgical procedure (median 36 days; range 0-1,261 days), and 16 of the 35 infections led to a device explantation. All but 1 of the infections involved only soft tissue, and cultures most often indicated skin flora; there were no instances of meningitis or brain parenchymal infection. ${ }^{13,14}$

Other device-related SAEs included non-seizure-related hemorrhage in 7 patients (2.7\%), 4 of which occurred within a few days of an implantation procedure and had no neurologic sequelae. Status epilepticus occurred in $8.2 \%$ of participants during the study; $52 \%$ (15 of 29) of the events were nonconvulsive status epilepticus. The majority of these events were not device related (26 of 29) and were considered serious (27 of 29 ) due to hospitalization.

\section{Depression and suicidality}

At enrollment in the RNS System studies, $60 \%$ of all participants reported a medical history of depression, suicidality, or both. Cumulatively, 1.6\% (4 of 256) of participants reported an SAE related to depression, and $23.4 \%$ ( 60 of 256 ) reported a mild $\mathrm{AE}$; the majority of these participants ( $71 \%$ ) had a medical history of depression. The majority of AEs associated with depression $(82 \%)$ were not considered to be device related.

AEs related to suicidality (suicidal depression, suicidal ideation, suicidal behavior, and suicide attempts) were reported in $9.8 \%$ of participants over the 9 years; $68 \%$ of the events were considered serious, and the majority of these participants $(86 \%)$ had a history of depression. In addition, 2 patients completed suicide, 1 of whom was being treated with brainresponsive neurostimulation at the time. Both had a history of depression, and 1 also had a history of suicidality.

\section{Memory}

Only 1 participant reported an SAE related to memory. $\mathrm{Cu}-$ mulatively, $12.5 \%$ of patients had a non-device-related $\mathrm{AE}$ (typically mild) related to memory impairment over the 9 years. AEs related to memory impairment occurred most often in patients who reported memory impairment before enrollment (69\%).

\section{SUDEP findings}

There were 16 deaths in the 256 patients over the 9 years of follow-up: 2 due to suicide; 1 each due to status epilepticus, 


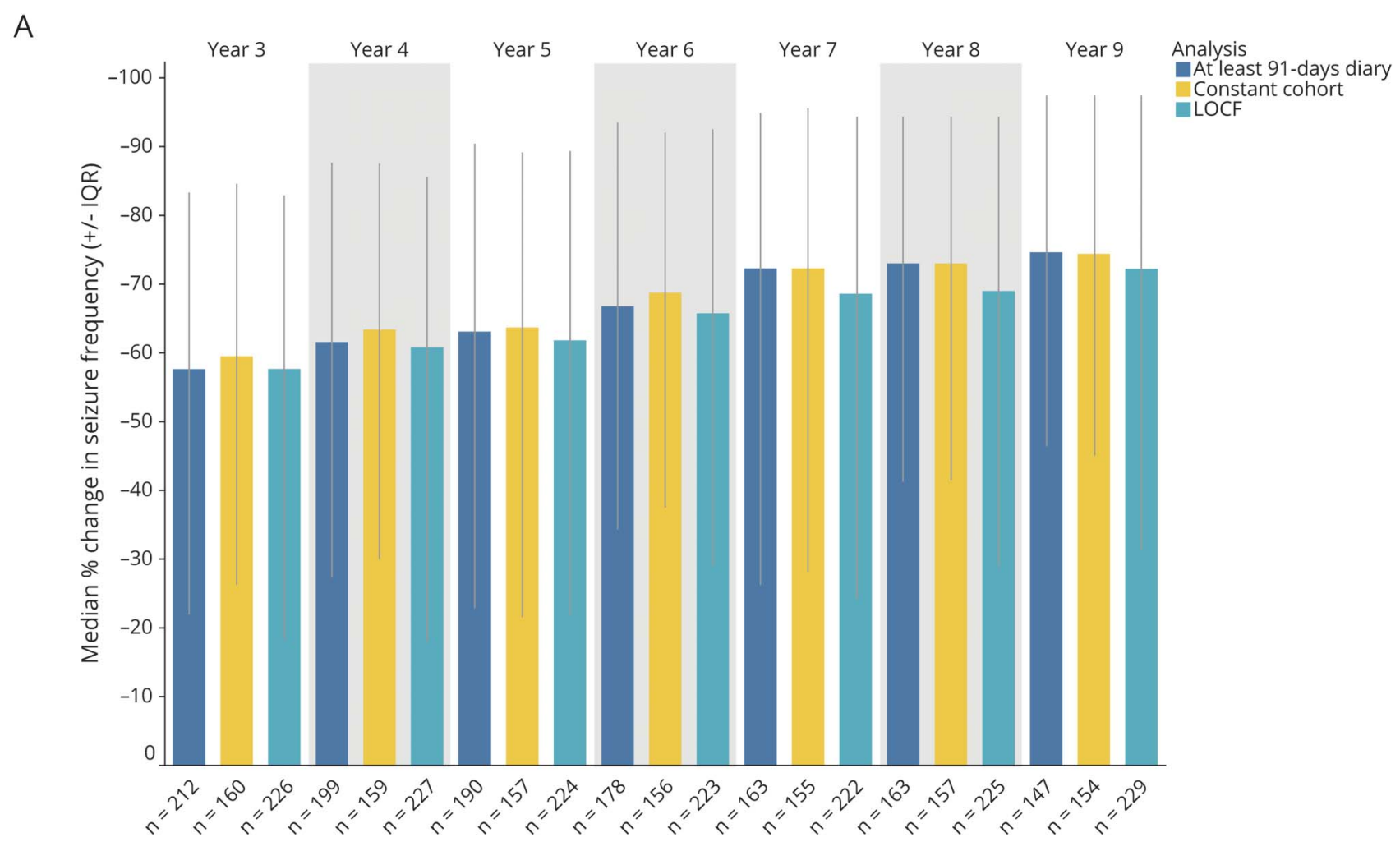

B

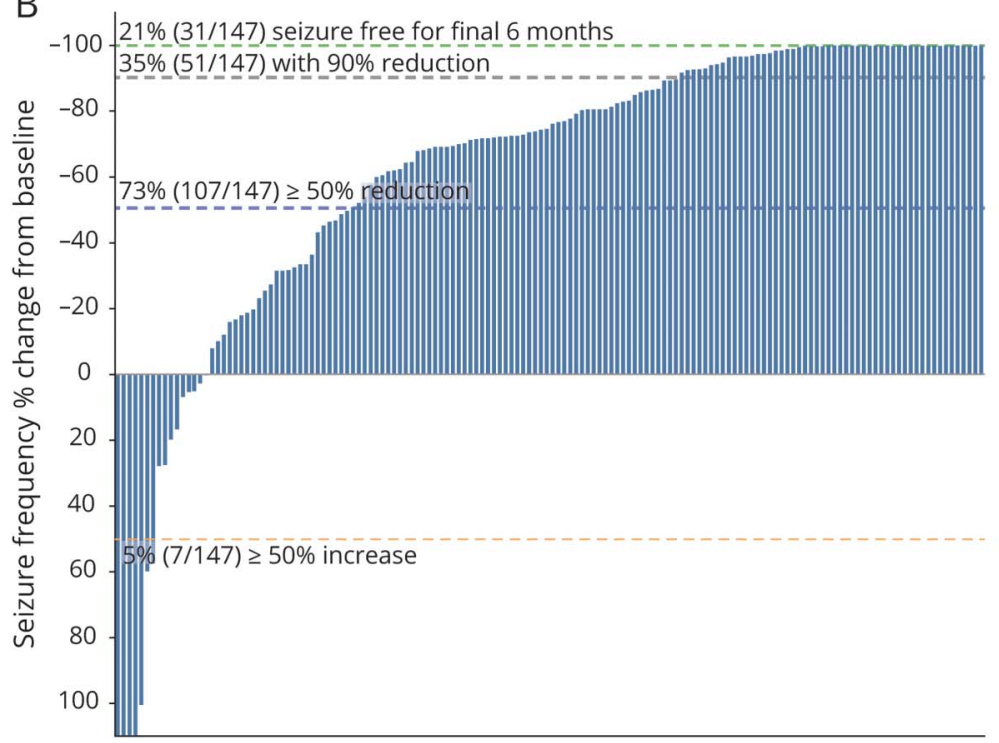

C

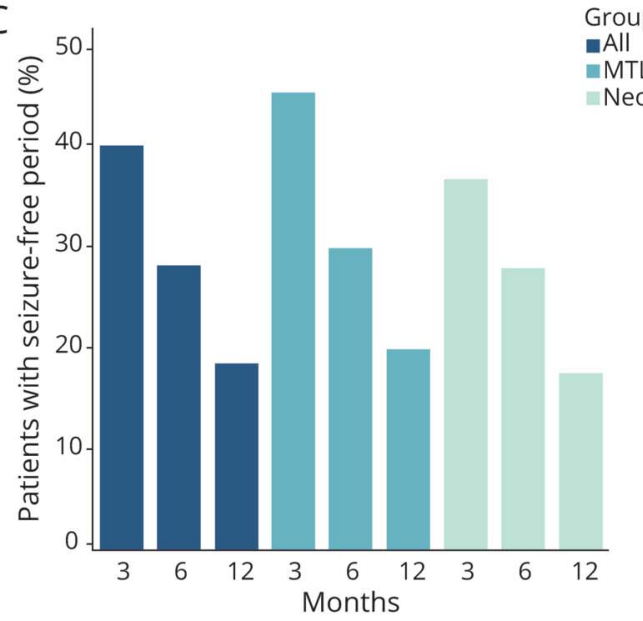

Plot showing the median percent reduction \pm IQR in seizure frequency for the last 6 months of each year in the long-term treatment study (years 3 through 9 of treatment) compared to baseline for the 91-day minimum diary requirement population, the constant cohort population, and the last observation carried forward (LOCF) population. (A) Median percent reduction \pm interquartile range (IQR) over time. (B) Individual changes in clinical seizure frequency. Changes in clinical seizure frequency during the last 6 months of follow-up before the year 9 visit for each participant who had at least 91 days of seizure diary data. Negative values indicate a seizure frequency reduction compared with baseline. (C) Bar graph showing the percent of all participants (All) and participants with onsets in the mesial temporal lobe (MTL) or neocortex (Neo) with at least 1 period of seizure freedom lasting at least 3, 6, and 12 months.

herpes encephalitis, sepsis, lung/colon cancer, and lymphoma; 4 due to definite SUDEP; 2 due to probable SUDEP; and 3 due to possible SUDEP. Two of the patients who had SUDEP were not being treated with brain-responsive neurostimulation at the time of death. The rate of probable or definite SUDEP combined was 2.8 per 1,000 patientstimulation years (95\% confidence interval [CI] 1.2-6.7) and 3.2 per 1,000 patient-implantation years $(95 \% \mathrm{CI}$ 1.4-7.0). This is lower than the prespecified comparator of 9.3 per 1,000 patient-years for patients who are epilepsy surgery 
Table 2 LOCF seizure frequency reduction and responder rates based on antiseizure medication changes

\begin{tabular}{llll}
\hline Changes in antiseizure medications & No. & ${\text { Median change }{ }^{\mathrm{a}}(\mathrm{IQR}), \%}$ & Responder rate, ${ }^{a} \%(\mathrm{n} / \mathrm{N})$ \\
\hline No change & 22 & $-71(-35$ to -92$)$ & $64(14 / 22)$ \\
\hline Increase & 52 & $-68(-12$ to -82$)$ & $63(33 / 52)$ \\
\hline Mixed (increase and decrease) & 139 & $-73(-32$ to -97$)$ & $68(94 / 139)$ \\
\hline Decrease & 16 & $-96(-61$ to -100$)$ & $75(12 / 16)$ \\
\hline
\end{tabular}

Abbreviations: IQR = interquartile range; $L O C F=$ last observation carried forward.

a LOCF most recent 6 months of follow-up.

Copyright @ 2020 NeuroPace, Inc.

candidates and statistically significantly lower than the comparator of 6.9 per 1,000 patient-years for patients with medically intractable epilepsy in the placebo arm of randomized controlled medication trials $\left(p<0.05,1\right.$-tailed $\left.\chi^{2}\right) .{ }^{15}$

\section{Neurostimulator battery longevity}

The Kaplan-Meier survival analysis of the RNS-300M neurostimulator model found the median time to replacement to be $\approx 1,284$ days or 3.5 years. For the RNS-300M neurostimulator, there were no device malfunctions related to the battery.

\section{Discussion}

Treatment with the RNS System significantly and progressively improved seizures over 9 years of prospective follow-up. At the completion of 9 years of treatment, the median percent seizure reduction was $75 \%$, the responder rate was $73 \%$, and more than one-third of patients had a $\geq 90 \%$ reduction in seizures. Unlike antiepileptic medications, ${ }^{16}$ the clinical response to brainresponsive neurostimulation improved over time. The analysis of the completed study showed a progressive improvement in seizure frequency through the end of 9 years of treatment. This contrasts with the previously published interim analysis ${ }^{8}$ that found improvement in seizure frequency through the first 2 years followed by a plateau in response. The discrepancy is likely due to the smaller sample size at later time points in the interim analysis while the study was ongoing. The progressive improvement through 9 years of follow-up is consistent with other neuromodulation modalities ${ }^{7}$ and suggests that there could be longer-term neuromodulatory effects of neurostimulation that result in continued improvement in outcomes.

Many patients had long seizure-free periods. At the completion of the study, $21 \%$ of patients were seizure-free. Over the course of the study, $28 \%$ of patients were seizure-free for at least 1 period of $\geq 6$ months, and $18 \%$ had at least 1 period of $\geq 12$ months without seizures. In addition, patients with at least 1 year of seizure freedom experienced an average period of 3.2 years without a seizure. These results are especially meaningful when we consider that these patients had a nearly 20 -year history of epilepsy, had $>10$ disabling seizures a month at baseline, and had failed multiple epilepsy therapies.

Significant seizure reductions were similarly likely in patients with and without prior brain resective surgery, VNS, or intracranial monitoring; in patients with seizures arising from the mesial temporal lobe or neocortex; for those with 1 or 2 foci; and for those with and without a lesion on brain MRI.

Table 3 Seizure frequency reduction and responder rates at 9 years according to region of seizure onset

\begin{tabular}{|c|c|c|}
\hline Region of seizure onset & Median reduction (IQR), \% & Responder rate, $\%$ \\
\hline All MTL $(n=66)$ & $73(58-96)$ & 77 \\
\hline MTL bilateral $(n=48)$ & $71.9(56-90)$ & 77 \\
\hline MTL unilateral $(n=18)$ & $94(64-100)$ & 78 \\
\hline All temporal $(n=95)$ MTL, lateral, MTL + lateral & $73(47-93)$ & 72 \\
\hline All neocortical $(n=70)$ & $81(34-100)$ & 70 \\
\hline Lateral temporal $(n=19)$ & $81(33-99)$ & 58 \\
\hline Frontal $(n=21)$ & $93(31-100)$ & 71 \\
\hline Other $(n=30)$ & $79(52-93)$ & 77 \\
\hline
\end{tabular}

Abbreviations: IQR = interquartile range; $\mathrm{MTL}$ = mesial temporal lobe.

Copyright (C) 2020 NeuroPace, Inc. 
The reduction in seizures with RNS System treatment was not significantly associated with changes in antiseizure medications. While there were no apparent differences in seizure frequency reductions for these different subgroups in the clinical study, it should be noted that the study was not powered for subgroup comparisons. As a result, larger sample sizes may be needed to identify the characteristics of patients who are most likely to benefit from brain-responsive neurostimulation.

The response to treatment with the RNS System is supported by significant and sustained improvements in overall QOL and in individual domains of QOL that indicate less vulnerability to seizures and a more positive perception of cognitive function. These are areas of function that are often profoundly affected in persons with intractable seizures. ${ }^{17,18}$

Responsive neurostimulation was well tolerated and safe over time. AEs related to the implanted device, including infection, were anticipated, and the rates were not higher than reported with implantation of intracranial electrodes to localize the seizure focus, ${ }^{19-21}$ with resective epilepsy surgery, ${ }^{19,22,23}$ or with DBS devices for treatment of movement disorders ${ }^{24}$ or for epilepsy. ${ }^{6,7}$

Deaths, including deaths by SUDEP, were not more frequent than is expected in patients with medically intractable focal onset seizures, ${ }^{25,26}$ and the SUDEP rate was significantly lower than the prespecified comparator estimate of 9.3 per 1,000 patient years. An analysis of SUDEP events in a larger population of patients treated with the RNS System $(n=707)$ provides a more confident estimate of the SUDEP risk, with a rate of probable and definite SUDEP of 2.0 per 1,000 patient-stimulation years $(95 \%$ CI $0.9-5.4) .{ }^{27}$

The risk for infection is $4.1 \%$ with each RNS Neurostimulator procedure and was previously shown not to increase with subsequent routine neurostimulator replacements. ${ }^{13}$ This compares favorably to other neurostimulation therapies that use a pectorally implanted pulse generator such as $\mathrm{VNS}^{28}$ and DBS for Parkinson disease ${ }^{24}$ or epilepsy. ${ }^{6,7}$

Depression comorbidity in patients with medically intractable focal onset seizures reaches $66 \% .{ }^{29}$ Validated inventories of depression (Beck Depression Inventory, Center for Epidemiologic Studies Depression) showed that there was no deterioration in mood in patients treated with the RNS System during the randomized controlled trial, ${ }^{10}$ and there were modest group improvements. ${ }^{30}$ Patients in the RNS System trials who had a history of depression, suicidality, or both were more likely to experience AEs related to depression or suicidality.

AEs related to memory impairment were infrequent in patients treated with brain-responsive neurostimulation, were almost all mild, and were predominantly from patients with a history of memory impairment.
In the RNS System randomized controlled trial, there was no deterioration in any of 14 cognitive domains over 2 years. Verbal fluency improved significantly in patients with seizure onsets in neocortical regions. In addition, there were small but statistically significant improvements in verbal memory that were specific to patients with seizures arising from the mesial temporal lobe. ${ }^{31}$ These results contrast sharply with memory outcomes after temporal lobectomy or selective amygdalohippocampectomy, after which significant declines in verbal memory may occur, particularly following dominant hemisphere procedures. ${ }^{32,33}$ Small but statistically significant cognitive declines in verbal and narrative memory have also been reported after laser interstitial thermal therapy for mesial temporal lobe epilepsy, particularly in the dominant hemisphere. ${ }^{34}$

The neurostimulator battery longevity for the RNS-300M model observed in the clinical trial was consistent with that anticipated by the battery longevity estimates provided in the user manual, which indicates a time to end of service of 2.6 to 4.2 years, depending on the device settings. ${ }^{35}$ This is shorter than observed for the Kinetra and Activa-PC DBS neurostimulators on the basis of experience in Parkinson disease for which the median survival was 6.5 and 4.6 years, respectively. ${ }^{36}$ However, the newest neurostimulator model (RNS-320) is anticipated to increase battery longevity to 8 years at moderate stimulation use.

While the RNS System provides a considerable amount of ambulatory ECoG data that necessitate interpretation by the physician, these ECoG data may provide insights relevant to the clinical care of persons with epilepsy. For example, RNS System long-term ECoG data have been used to refine localization of the seizure onset and to inform decisions about resective or ablative surgery. ${ }^{37-39}$ ECoG data may provide an early indication of the clinical response to antiseizure medications ${ }^{40}$ and to changes in lifestyle. ${ }^{41}$ In addition, recent studies have shown that features in the ECoG data may provide objective biomarkers that can be used to assess the clinical response to stimulation. ${ }^{42,43}$ In addition, it may be possible to use an individual patient's ECoG data to identify periods of heightened seizure risk. ${ }^{44,45}$ In the future, these data may be used to supplement the patient's clinical report. However, these potential biomarkers require further research and validation before they can be widely used in the RNS System patient population.

The results are provided from an open-label long-term study and may be influenced by selection bias, expectation bias, a prolonged placebo response, or regression to the mean. However, a significant improvement was evident in treated patients compared to sham-stimulated patients in the blinded portion of a randomized controlled trial, and an improvement in the sham-stimulated patients was evident when stimulation was first provided, despite maintenance of the randomization blind. In addition, these patients had a 20-year history of intractable epilepsy on average, so it is unlikely that sustained and 
significant 9-year reductions would be observed. Finally, such long-term experience could not be feasibly obtained in a blinded and randomized trial.

The long-term efficacy and safety of brain-responsive neurostimulation for the treatment of medically intractable focal seizures are established on the basis of results in 256 patients who were followed up prospectively for a median of 9 years. As with all other epilepsy therapies, there was a range of patient responses. However, this study provides substantial evidence that adjunctive treatment with brain-responsive neurostimulation is safe and provides persons with medically intractable focal epilepsy an opportunity for significant and sustained reductions in disabling seizures with enduring improvements in QOL, as well as SUDEP rates that were lower than anticipated for similar patient populations. The safety of the surgical procedure and the implanted device compares favorably to other brain stimulation devices used for the treatment of movement disorders ${ }^{24}$ and epilepsy. ${ }^{7}$

Future research will explore methods by which brainresponsive neurostimulation can be optimized for individual patients with medically intractable epilepsy. With machine and deep learning techniques, clinical and ECoG data features may be identified that can direct personalized neurostimulator detection and stimulation programming. Additional work to define the short- and long-term mechanism(s) of action may help to determine the optimal application of these devices.

\section{Acknowledgment}

The authors thank the patients and families for participating in the RNS System trials. They also thank the members of the Data Safety Monitoring Board, who were responsible for independently monitoring the safety of interventions by reviewing data during the RNS System trials, and members of the SUDEP Analysis Committee, who were responsible for reviewing data regarding any deaths that occur for participants participating in the RNS System trials. Data Safety Monitoring Board: Roger Porter, MD (chair), Gary Mathern, MD, Joan Conry, MD, John "Jack" Pellock, MD (in memoriam), Lorene Nelson, $\mathrm{PhD}$, and Dan Bloch, PhD. SUDEP Analysis Committee: W. Allen Hauser, MD (chair), Thaddeus Walczak, MD, and Terri Haddix. In addition, they thank the following individuals who served as clinical study coordinators and contributed to the research conducted (protocol procedures, data collection, and data entry): California Pacific Medical Center, San Francisco, CA. Douglas Raggett, RN, and Anna von Bakonyi, LVN, CCRC; Augusta University, Augusta, GA: Patty Ray, PhD; Henry Ford Hospital, Detroit, MI: Helen Foley, Carla Sandles, and Kelly Tundo, RN, BSN; Swedish Neuroscience Institute, Seattle, WA: Caryl Tongco, CCRP; Mayo Clinic Arizona, Scottsdale, AZ: Erica Boyd, RN, BSN; Johns Hopkins Medicine, Baltimore, MD: Joanne Barnett and Pam Coe; Keck School of Medicine of USC, Los Angeles, CA: Guadalupe Corral-Leyva and Sandra Oviedo: Yale University School of Medicine, New Haven, CT: Jennifer Bonito; Mayo
Clinic Florida, Jacksonville, FL: Karey Doll, PhD, BSN, RN, and Sabrina Selman; Rush University Medical Center, Chicago, IL: Diana Miazga; Columbia University Medical Center, New York, NY: Camilla Casadei; University of Texas Southwestern Medical Center, Dallas, TX: Nasreen Sayed, MS; Cleveland Clinic Foundation, Cleveland, OH: Chenett Greer, MEd, CCRP, Xiaoming Zhang, PhD, and Michael Mackow, RN; Geisel School of Medicine at Dartmouth, Hanover, NH: Faith Alexandre, CCRP; Indiana University School of Medicine, Indianapolis, IN: Abigail Klaehn, RN, BSN, and Linda Perdue; Massachusetts General Hospital, Boston, MA: S. Anthony Siena; Mayo Clinic Minnesota, Rochester, MN: Karla Crockett and Cindy Nelson; Medical University of South Carolina, Charleston: Becky Hamrick; Oregon Health \& Science University, Portland, OR: Chad Sorenson; Nicklaus Children's Hospital, Miami, FL. Tami Quintero, BS, CCRC; Saint Barnabas Medical Center, Livingston, NJ: Elaine DeCarlo, $\mathrm{RN}$, and Jade Misajon, RN; University of Rochester Medical Center, Rochester, NY: Noreen Connelly, MS, JD, CRCC, and Diane Smith, CCRP; University of Wisconsin Hospital \& Clinics, Madison, WI: Andrea Maser and Christopher Roginski; Baylor College of Medicine, Houston, TX: Ronnie S Tobias, DNP, ANP-C; Emory University School of Medicine, Atlanta, GA: Yvan A Bamps, PhD, Diane Teagarden, APRNBC, ANP, MSN, and Emilee Wehunt; George Washington University School of Medicine \& Health Sciences, Washington, DC: Diane Rothrock and Stacy Tam; Weill Cornell Medical College, New York, NY: Bill Nikolov, MD; University of Virginia School of Medicine, Charlottesville, VA: Bruce Palmer and Stacy Thompson, RN, BSN, CCRC; University of Florida, Gainesville, Gainesville, FL: Amanda James; and Wake Forest University Health Sciences, Winston-Salem, NC: Jessica Dimos. Douglas R. Labar, MD, PhD, is deceased. The statistical analysis was performed by Tami Crabtree and Brian Johnson, Advance Research Associates Inc, Santa Clara, CA.

\section{Study funding}

NeuroPace, Inc. provided funding for the clinical study and is responsible for the study design. All investigator authors were responsible for data collection. The sponsor, lead author, and other investigator authors contributed to data interpretation and preparation/review of the manuscript.

\section{Disclosure}

D. Nair has received travel or speaker honorarium from Medtronic, has consulted for NeuroPace, has been on the speakers' bureau for NeuroPace, has received research effort from the $\mathrm{NIH}$ and NeuroPace, and has received research support from Brain Sentinel and NeuroPace. K. Laxer reports no disclosures relevant to the manuscript. P. Weber has consulted for NeuroPace. A. Murro and Y. Park report no disclosures relevant to the manuscript. G. Barkley has been on the speakers' bureau for NeuroPace and has received research support from the NIH and NeuroPace. B. Smith has received travel and honorarium for being on the scientific advisory board for NeuroPace SK Life Science and UCB, has received research effort from NeuroPace, 
and is an active clinician who will be prescribing the RNS System as a treatment option. R. Gwinn, M. Doherty, and K. Noe report no disclosures relevant to the manuscript. R. Zimmerman has consulted for Medtronic on robotic instruments. G. Bergey has been an associate editor for Neurotherapeutics. W. Anderson has served on the advisory board of Longeviti, has consulted for Globus Medical, and has received research support from the NIH. C. Heck has received research support from NeuroPace. C. Liu, R. Lee, T. Sadler, and R. Duckrow report no disclosures relevant to the manuscript. L. Hirsch has received research support to Yale University for investigator-initiated studies from Monteris Medical, Upsher-Smith Laboratories, and The Daniel Raymond Wong Neurology Research Fund at Yale; consultation fees for advising from Adamas Pharmaceuticals, Aquestive Therapeutics, CeriBell, Eisai Co, Medtronic, and UCB; royalties from Neurology and Wiley; and honorarium for speaking for NeuroPace. R. Wharen reports no disclosures relevant to the manuscript. W. Tatum has received a stipend as Editor-in-Chief of Epilepsy Behavior Case Report, been awarded and pending patents, received royalties from Demos Publishers Inc and Springer Publishing, received research support from Eisai Co (pending) and the Martin Family Foundation (in-kind donation), and served as an expert witness on behalf of the Epilepsy Foundation of America (EFA), monies donated to EFA. S. Srinivasan:was the principal investigator at Columbia for the RNS System LTT study, sponsored by NeuroPace. G. McKhann has served on the publication committee of Stereotactic Laser Ablation for Mesial Temporal Lobe Epilepsy (SLATE) trial and served as an investigator in the RNS System LTT study, sponsored by NeuroPace. M. Agostini participated in the RNS System clinical trials, sponsored by NeuroPace. A. Alexopoulos reports no disclosures relevant to the manuscript. B. Jobst has received research support from the Centers for Disease Control and Prevention, Defense Advanced Research Projects Agency, Eisai Co, Medtronic, the National Science Foundation, NeuroPace, and Sunovion. D. Roberts has served on the advisory board/panel of Neurosurgery, Journal of Neurosurgery, Neurologia medico-chirurgica, Zentralblatt für Neurochirurgie, and Journal of Neurologic Surgery Part A; has served on the editorial boards of Neurosurgery, Journal of Neurosurgery, and World Neurosurgery; has served as editor of Neurosurgical Focus and Stereotactic and Functional Neurosurgery; has awarded and pending patents; has consulted for the Department of Neurosurgery at Brigham and Women's Hospital; is cofounder and chief medical officer of InSight Surgical Technologies LLC (no salary); has received research support Carl Zeiss Meditec, DUSA Pharmaceuticals, Medtronic, and the NIH; and has stock or stock options in ODS Medical. V. Salanova was/is the principal investigator at Indiana University for the RNS System pivotal study and postapproval trial, sponsored by NeuroPace; the Stimulation of the Anterior Nucleus of the Thalamus for Epilepsy (SANTE) trial; the SLATE trial; and the NIH Radiosurgery vs Open Surgery for Epilepsy (ROSE) trial. T. Witt and S. Cash report no disclosures relevant to the manuscript. A. Cole has consulted for Biogen, Blackfynn, Boston Pharmaceuticals, Pfizer, Sage Therapeutics, and Takeda; received support for travel to an advisory meeting for NeuroPace; received speaking fees from Genentech; and served on data monitoring boards for Medtronic and Ovid Therapeutics. G. Worrell is a founder of and owns stock in Cadence Neuroscience. B. Lundstrom has served as an unpaid consultant for Cadence Neuroscience, which is co-owned by Mayo Clinic. J. Edwards reports no disclosures relevant to the manuscript. J. Halford has consulted for Cavion, NCGS Inc, Philips, and SK Life Science and has received research support from Greenwich Biosciences, Brain Sentinel, Philips, SK Life Science, Takeda, and The Epilepsy Study Consortium. D. Spencer has consulted for NeuroPace and receives travel or speaker honorarium from NeuroPace. L. Ernst received a 1-time honorarium from NeuroPace for speaking at an educational symposium, and Oregon Health \& Science University received financial support from NeuroPace for participation in the LTT Study. C. Skidmore has received research support from Cavion, Engage Therapeutics, Medtronic Navigation, Neurelis, Neuropace, UCB Biopharma SPRL, SK Life Science, the NIH, UCB Biosciences, and Xenon Pharmaceuticals and has consulted for NeuroPace. M. Sperling has served as editor-in-chief for Epilepsia; consulted for Medtronic (paid to Thomas Jefferson University); received research support from Cavion, Eisai, Engage Therapeutics, Medtronic, Neurelis, Pfizer, SK Life Science, Takeda, and UCB Pharma (paid to Thomas Jefferson University); and received publishing royalties from Oxford University Press. I. Miller has received research support, travel funds, or consulting fees from Biomarin, Dravet Syndrome Foundation, Greenwich Biosciences, Hope for $\mathrm{HH}$ Foundation, Insys Therapeudics, Insightec, NeuroPace, Neurelis, Tuberous Sclerosis Alliance, Ultragenyx, Upsher-Smith, and Zogenix. E. Geller has served as an investigator for the RNS System clinical trials, sponsored by NeuroPace; has consulted for NeuroPace; has been on the speakers' bureau for NeuroPace and Liva Nova; and prescribes and programs the RNS System in clinical practice. $\mathrm{M}$. Berg during the past 5 years has participated in research studies as a principal investigator or subinvestigator sponsored by US FDA, American Epilepsy Society, Epilepsy Foundation of America, NeuroPace Inc, Sunovian, Upsher-Smith Labs, Lundbeck, Pfizer, King Pharmacetuicals, Sage Therapeutics, Biogen, and Acorda Therapeutics. He is part owner of the following startups: PharmAdva LLC and Jemsico LLC. A. Fessler, P. Rutecki, and A. Goldman report no disclosures relevant to the manuscript. E. Mizrahi has received research support from NeuroPace and the US Department of Defense and royalties from McGraw-Hill Medical, Demos Medical Publishing, UpToDate, and Wolters Kluwers Publishers. R. Gross serves as a consultant to NeuroPace, Inc and receives compensation for these services. NeuroPace develops products related to the research described in this article. The terms of this arrangement have been reviewed and approved by Emory University in accordance with its conflict of interest policies. In addition, Dr. Gross has consulted for Abbott, Boston Scientific, Clearpoint, Medtronic, NeuroPace, St. Jude Medical, and Zimmer Biomet and received research support from the American Epilepsy Society, Citizens United for Research in Epilepsy, Defense Advanced Research Projects Agency, Mirkowski Foundation, NIH, and National Science Foundation. D. Shields has consulted, gratis, for Samitaur Medical Technologies and receives funding 
support as chief clinical investigator from US Army Medical Research and Materiel Command. T. Schwartz has consulted for Integra and is an investor in Mivi Neuroscience. D. Labar is deceased; disclosures are not included for this author. N. Fountain has received research support from Biogen, GW Pharma, Medtronic, Neuropace, SK Life Science, UCB, and Xenon and has been a medical monitor for Cerebral Therapeutics and Medtronic. W. Elias has received research support from Insightec. P. Olejniczak has been on the speakers' bureau for UCB Pharma. N. Villemarette-Pittman has been the managing editor of the Journal of the Neurologic Sciences (JNS) and received part of her salary and a travel honorarium from Elsevier for the annual JNS board meeting. S. Eisenschenk reports no disclosures relevant to the manuscript. S. Roper has consulted for Medtronic. J. Boggs has received research support through Liva Nova, Medtronic, NeuroPace, and UCB and has served on the advisory board of SK Life Science. T. Courtney certifies that she has equity ownership/stock options with NeuroPace and is an employee of NeuroPace. T. Sun certifies that she has equity ownership/stock options with NeuroPace, has been an employee of NeuroPace, and is currently a consultant for NeuroPace. C. Seale, K. Miller, T. Skarpaas, and M. Morrell certify that they have equity ownership/stock options with NeuroPace and are employees of NeuroPace. Go to Neurology.org/N for full disclosures.

\section{Publication history}

Received by Neurology March 21, 2019. Accepted in final form March 6, 2020.

\section{Appendix Authors}

\begin{tabular}{|c|c|c|}
\hline Name & Location & Contribution \\
\hline $\begin{array}{l}\text { Dileep R. } \\
\text { Nair, MD }\end{array}$ & $\begin{array}{l}\text { Cleveland Clinic } \\
\text { Foundation, } \mathrm{OH}\end{array}$ & $\begin{array}{l}\text { Major role in the } \\
\text { acquisition of data; } \\
\text { analysis or interpretation } \\
\text { of the data; drafting/ } \\
\text { revising manuscript for } \\
\text { intellectual content }\end{array}$ \\
\hline $\begin{array}{l}\text { Kenneth D. } \\
\text { Laxer, MD }\end{array}$ & $\begin{array}{l}\text { California Pacific Medical } \\
\text { Center, San Francisco }\end{array}$ & $\begin{array}{l}\text { Major role in the } \\
\text { acquisition of data }\end{array}$ \\
\hline $\begin{array}{l}\text { Peter B. } \\
\text { Weber, MD }\end{array}$ & $\begin{array}{l}\text { California Pacific Medical } \\
\text { Center, San Francisco }\end{array}$ & $\begin{array}{l}\text { Major role in the } \\
\text { acquisition of data }\end{array}$ \\
\hline $\begin{array}{l}\text { Anthony M. } \\
\text { Murro, MD }\end{array}$ & Augusta University, GA & $\begin{array}{l}\text { Major role in the } \\
\text { acquisition of data }\end{array}$ \\
\hline $\begin{array}{l}\text { Yong D. Park, } \\
\text { MD }\end{array}$ & Augusta University, GA & $\begin{array}{l}\text { Major role in the } \\
\text { acquisition of data }\end{array}$ \\
\hline $\begin{array}{l}\text { Gregory L. } \\
\text { Barkley, MD }\end{array}$ & $\begin{array}{l}\text { Henry Ford Hospital, } \\
\text { Detroit, MI }\end{array}$ & $\begin{array}{l}\text { Major role in the } \\
\text { acquisition of data }\end{array}$ \\
\hline $\begin{array}{l}\text { Brien J. } \\
\text { Smith, MD }\end{array}$ & $\begin{array}{l}\text { Ohio Health } \\
\text { Neuroscience, Columbus, } \\
\text { OH }\end{array}$ & $\begin{array}{l}\text { Major role in the } \\
\text { acquisition of data }\end{array}$ \\
\hline $\begin{array}{l}\text { Ryder P. } \\
\text { Gwinn, MD }\end{array}$ & $\begin{array}{l}\text { Swedish Neuroscience } \\
\text { Institute, Seattle, WA }\end{array}$ & $\begin{array}{l}\text { Major role in the } \\
\text { acquisition of data }\end{array}$ \\
\hline $\begin{array}{l}\text { Michael J. } \\
\text { Doherty, MD }\end{array}$ & $\begin{array}{l}\text { Swedish Neuroscience } \\
\text { Institute, Seattle, WA }\end{array}$ & $\begin{array}{l}\text { Major role in the } \\
\text { acquisition of data }\end{array}$ \\
\hline
\end{tabular}

\section{Appendix (continued)}

\begin{tabular}{lll}
\hline Name & Location & Contribution \\
\hline $\begin{array}{l}\text { Katherine H. } \\
\text { Noe, MD, PhD }\end{array}$ & $\begin{array}{l}\text { Mayo Clinic Arizona, } \\
\text { Scottsdale }\end{array}$ & $\begin{array}{l}\text { Major role in the } \\
\text { acquisition of data }\end{array}$ \\
\hline $\begin{array}{l}\text { Richard S. } \\
\text { Zimmerman, }\end{array}$ & $\begin{array}{l}\text { Mayo Clinic Arizona, } \\
\text { MD }\end{array}$ & $\begin{array}{l}\text { Major role in the acquisition } \\
\text { of data; drafting/revising } \\
\text { manuscript for intellectual } \\
\text { content }\end{array}$
\end{tabular}

\begin{tabular}{ll}
\hline Gregory K. & Johns Hopkins Medicine, \\
Bergey, MD & Baltimore, MD
\end{tabular}

Major role in the acquisition of data; drafting/revising manuscript for intellectual content

\begin{tabular}{lll}
\hline $\begin{array}{l}\text { William S. } \\
\text { Anderson, } \\
\text { MD, PhD }\end{array}$ & $\begin{array}{l}\text { Johns Hopkins Medicine, } \\
\text { Baltimore, MD }\end{array}$ & $\begin{array}{l}\text { Major role in the } \\
\text { acquisition of data }\end{array}$ \\
\hline $\begin{array}{l}\text { Christianne } \\
\text { Heck, MD }\end{array}$ & $\begin{array}{l}\text { Keck School of Medicine } \\
\text { of USC, Los Angeles, CA }\end{array}$ & $\begin{array}{l}\text { Major role in the } \\
\text { acquisition of data }\end{array}$ \\
\hline $\begin{array}{l}\text { Charles Y. } \\
\text { Liu, MD, PhD }\end{array}$ & $\begin{array}{l}\text { Keck School of Medicine } \\
\text { of USC, Los Angeles, CA }\end{array}$ & $\begin{array}{l}\text { Major role in the } \\
\text { acquisition of data }\end{array}$ \\
\hline $\begin{array}{l}\text { Ricky W. Lee, } \\
\text { MD }\end{array}$ & $\begin{array}{l}\text { Via Christi Epilepsy } \\
\text { Center, Wichita, KS }\end{array}$ & $\begin{array}{l}\text { Major role in the } \\
\text { acquisition of data }\end{array}$ \\
\hline $\begin{array}{l}\text { Toni Sadler, } \\
\text { PA-C }\end{array}$ & $\begin{array}{l}\text { Via Christi Epilepsy } \\
\text { Center, Wichita, KS }\end{array}$ & $\begin{array}{l}\text { Major role in the } \\
\text { acquisition of data }\end{array}$ \\
\hline $\begin{array}{l}\text { Robert B. } \\
\text { Duckrow, MD }\end{array}$ & $\begin{array}{l}\text { Yale University School of } \\
\text { Medicine, New Haven, CT }\end{array}$ & $\begin{array}{l}\text { Major role in the } \\
\text { acquisition of data }\end{array}$ \\
\hline $\begin{array}{l}\text { Lawrence J. } \\
\text { Hirsch, MD }\end{array}$ & $\begin{array}{l}\text { Yale University School of } \\
\text { Medicine, New Haven, CT }\end{array}$ & $\begin{array}{l}\text { Major role in the } \\
\text { acquisition of data; } \\
\text { drafting/revising } \\
\text { manuscript for intellectual } \\
\text { content }\end{array}$ \\
\hline
\end{tabular}

\begin{tabular}{lll}
\hline $\begin{array}{l}\text { Robert E. } \\
\text { Wharen, Jr., } \\
\text { MD }\end{array}$ & $\begin{array}{l}\text { Mayo Clinic Florida, } \\
\text { Jacksonville }\end{array}$ & $\begin{array}{l}\text { Major role in the } \\
\text { acquisition of data }\end{array}$ \\
\hline $\begin{array}{l}\text { William } \\
\text { Tatum, Do }\end{array}$ & $\begin{array}{l}\text { Mayo Clinic Florida, } \\
\text { Jacksonville }\end{array}$ & $\begin{array}{l}\text { Major role in the } \\
\text { acquisition of data }\end{array}$ \\
\hline $\begin{array}{l}\text { Shraddha } \\
\text { Srinivasan, } \\
\text { MD }\end{array}$ & $\begin{array}{l}\text { Columbia University } \\
\text { Medical Center, New York, }\end{array}$ & $\begin{array}{l}\text { Major role in the } \\
\text { acquisition of data; } \\
\text { drafting/revising } \\
\text { manuscript for intellectual } \\
\text { content }\end{array}$
\end{tabular}

\begin{tabular}{lll}
\hline $\begin{array}{l}\text { Guy M. } \\
\text { McKhann, } \\
\text { MD }\end{array}$ & $\begin{array}{l}\text { Columbia University } \\
\text { Nedical Center, New York, } \\
\text { NY }\end{array}$ & $\begin{array}{l}\text { Major role in the } \\
\text { acquisition of data }\end{array}$ \\
\hline $\begin{array}{l}\text { Mark A. } \\
\text { Agostini, MD }\end{array}$ & $\begin{array}{l}\text { University of Texas } \\
\text { Southwestern Medical } \\
\text { Center, Dallas }\end{array}$ & $\begin{array}{l}\text { Major role in the } \\
\text { acquisition of data }\end{array}$ \\
\hline $\begin{array}{l}\text { Andreas V. } \\
\text { Alexopoulos, } \\
\text { MD }\end{array}$ & $\begin{array}{l}\text { Cleveland Clinic } \\
\text { Foundation, OH }\end{array}$ & $\begin{array}{l}\text { Major role in the } \\
\text { acquisition of data }\end{array}$ \\
\hline $\begin{array}{l}\text { Barbara C. } \\
\text { Jobst, MD }\end{array}$ & $\begin{array}{l}\text { Geisel School of Medicine } \\
\text { at Dartmouth, Hanover, }\end{array}$ & $\begin{array}{l}\text { Major role in the } \\
\text { acquisition of data }\end{array}$ \\
$\begin{array}{lll}\text { NH } \\
\text { David W. } \\
\text { Roberts, MD }\end{array}$ & $\begin{array}{l}\text { Geisel School of Medicine } \\
\text { at Dartmouth, Hanover, }\end{array}$ & $\begin{array}{l}\text { Major role in the } \\
\text { acquisition of data }\end{array}$ \\
\hline $\begin{array}{l}\text { NH } \\
\text { Vicenta }\end{array}$ & $\begin{array}{l}\text { Indiana University School } \\
\text { of Medicine, Indianapolis }\end{array}$ & $\begin{array}{l}\text { Major role in the } \\
\text { acquisition of data }\end{array}$ \\
\hline
\end{tabular}


Appendix (continued)

\begin{tabular}{|c|c|c|}
\hline Name & Location & Contribution \\
\hline $\begin{array}{l}\text { Thomas C. } \\
\text { Witt, MD }\end{array}$ & $\begin{array}{l}\text { Goodman Campbell Brain } \\
\text { and Spine, Indianapolis, } \\
\text { IN }\end{array}$ & $\begin{array}{l}\text { Major role in the } \\
\text { acquisition of data }\end{array}$ \\
\hline $\begin{array}{l}\text { Sydney S. } \\
\text { Cash, MD, } \\
\text { PhD }\end{array}$ & $\begin{array}{l}\text { Massachusetts General } \\
\text { Hospital, Boston }\end{array}$ & $\begin{array}{l}\text { Major role in the } \\
\text { acquisition of data }\end{array}$ \\
\hline $\begin{array}{l}\text { Andrew J. } \\
\text { Cole, MD }\end{array}$ & $\begin{array}{l}\text { Massachusetts General } \\
\text { Hospital, Boston }\end{array}$ & $\begin{array}{l}\text { Major role in the } \\
\text { acquisition of data }\end{array}$ \\
\hline $\begin{array}{l}\text { Gregory A. } \\
\text { Worrell, MD, } \\
\text { PhD }\end{array}$ & $\begin{array}{l}\text { Mayo Clinic Minnesota, } \\
\text { Rochester }\end{array}$ & $\begin{array}{l}\text { Major role in the acquisition } \\
\text { of data; drafting/revising } \\
\text { manuscript for intellectual } \\
\text { content }\end{array}$ \\
\hline $\begin{array}{l}\text { Brian N. } \\
\text { Lundstrom, } \\
\text { MD, PhD }\end{array}$ & $\begin{array}{l}\text { Mayo Clinic Minnesota, } \\
\text { Rochester }\end{array}$ & $\begin{array}{l}\text { Major role in the } \\
\text { acquisition of data; } \\
\text { drafting/revising } \\
\text { manuscript for intellectual } \\
\text { content }\end{array}$ \\
\hline $\begin{array}{l}\text { Jonathan C. } \\
\text { Edwards, MD }\end{array}$ & $\begin{array}{l}\text { Medical University of } \\
\text { South Carolina, } \\
\text { Charleston }\end{array}$ & $\begin{array}{l}\text { Major role in the } \\
\text { acquisition of data }\end{array}$ \\
\hline $\begin{array}{l}\text { Jonathan J. } \\
\text { Halford, MD }\end{array}$ & $\begin{array}{l}\text { Medical University of } \\
\text { South Carolina, } \\
\text { Charleston }\end{array}$ & $\begin{array}{l}\text { Major role in the } \\
\text { acquisition of data }\end{array}$ \\
\hline $\begin{array}{l}\text { David C. } \\
\text { Spencer, MD }\end{array}$ & $\begin{array}{l}\text { Oregon Health \& Science } \\
\text { University, Portland }\end{array}$ & $\begin{array}{l}\text { Major role in the } \\
\text { acquisition of data }\end{array}$ \\
\hline Lia Ernst, MD & $\begin{array}{l}\text { Oregon Health \& Science } \\
\text { University, Portland }\end{array}$ & $\begin{array}{l}\text { Major role in the } \\
\text { acquisition of data }\end{array}$ \\
\hline $\begin{array}{l}\text { Christopher } \\
\text { T. Skidmore, } \\
\text { MD }\end{array}$ & $\begin{array}{l}\text { Thomas Jefferson } \\
\text { University, Philadelphia, } \\
\text { PN }\end{array}$ & $\begin{array}{l}\text { Major role in the } \\
\text { acquisition of data }\end{array}$ \\
\hline $\begin{array}{l}\text { Michael R. } \\
\text { Sperling, MD }\end{array}$ & $\begin{array}{l}\text { Thomas Jefferson } \\
\text { University, Philadelphia, } \\
\text { PN }\end{array}$ & $\begin{array}{l}\text { Major role in the } \\
\text { acquisition of data; } \\
\text { drafting/revising } \\
\text { manuscript for intellectual } \\
\text { content }\end{array}$ \\
\hline $\begin{array}{l}\text { Ian Miller, } \\
\text { MD }\end{array}$ & $\begin{array}{l}\text { Nicklaus Children's } \\
\text { Hospital, Miami, FL }\end{array}$ & $\begin{array}{l}\text { Major role in the } \\
\text { acquisition of data }\end{array}$ \\
\hline $\begin{array}{l}\text { Eric B. Geller, } \\
\text { MD }\end{array}$ & $\begin{array}{l}\text { Saint Barnabas Medical } \\
\text { Center, Livingston, NJ }\end{array}$ & $\begin{array}{l}\text { Major role in the } \\
\text { acquisition of data }\end{array}$ \\
\hline $\begin{array}{l}\text { Michel J. } \\
\text { Berg, MD }\end{array}$ & $\begin{array}{l}\text { University of Rochester } \\
\text { Medical Center, NY }\end{array}$ & $\begin{array}{l}\text { Major role in the } \\
\text { acquisition of data }\end{array}$ \\
\hline $\begin{array}{l}\text { A. James } \\
\text { Fessler, MD }\end{array}$ & $\begin{array}{l}\text { University of Rochester } \\
\text { Medical Center, NY }\end{array}$ & $\begin{array}{l}\text { Major role in the } \\
\text { acquisition of data }\end{array}$ \\
\hline $\begin{array}{l}\text { Paul Rutecki, } \\
\text { MD }\end{array}$ & $\begin{array}{l}\text { University of Wisconsin } \\
\text { Hospital and Clinics, } \\
\text { Madison }\end{array}$ & $\begin{array}{l}\text { Major role in the } \\
\text { acquisition of data }\end{array}$ \\
\hline $\begin{array}{l}\text { Alica M. } \\
\text { Goldman, } \\
\text { MD, PhD }\end{array}$ & $\begin{array}{l}\text { Baylor College of } \\
\text { Medicine, Houston, TX }\end{array}$ & $\begin{array}{l}\text { Major role in the } \\
\text { acquisition of data }\end{array}$ \\
\hline $\begin{array}{l}\text { Eli M. } \\
\text { Mizrahi, MD }\end{array}$ & $\begin{array}{l}\text { Baylor College of } \\
\text { Medicine, Houston, TX }\end{array}$ & $\begin{array}{l}\text { Major role in the } \\
\text { acquisition of data }\end{array}$ \\
\hline $\begin{array}{l}\text { Robert E. } \\
\text { Gross, MD, } \\
\text { PhD }\end{array}$ & $\begin{array}{l}\text { Emory University School } \\
\text { of Medicine, Atlanta, GA }\end{array}$ & $\begin{array}{l}\text { Major role in the } \\
\text { acquisition of data }\end{array}$ \\
\hline
\end{tabular}

Appendix (continued)

\begin{tabular}{|c|c|c|}
\hline Name & Location & Contribution \\
\hline $\begin{array}{l}\text { Donald C. } \\
\text { Shields, MD }\end{array}$ & $\begin{array}{l}\text { George Washington } \\
\text { University School of } \\
\text { Medicine and Health } \\
\text { Sciences, Washington, DC }\end{array}$ & $\begin{array}{l}\text { Major role in the } \\
\text { acquisition of data }\end{array}$ \\
\hline $\begin{array}{l}\text { Theodore H. } \\
\text { Schwartz, MD }\end{array}$ & $\begin{array}{l}\text { Weill Cornell Medical } \\
\text { College, New York, NY }\end{array}$ & $\begin{array}{l}\text { Major role in the } \\
\text { acquisition of data }\end{array}$ \\
\hline $\begin{array}{l}\text { Douglas R. } \\
\text { Labar, MD, } \\
\text { PhD }\end{array}$ & $\begin{array}{l}\text { Weill Cornell Medical } \\
\text { College, New York, NY }\end{array}$ & $\begin{array}{l}\text { Major role in the } \\
\text { acquisition of data }\end{array}$ \\
\hline $\begin{array}{l}\text { Nathan B. } \\
\text { Fountain, MD }\end{array}$ & $\begin{array}{l}\text { University of Virginia } \\
\text { School of Medicine, } \\
\text { Charlottesville }\end{array}$ & $\begin{array}{l}\text { Major role in the } \\
\text { acquisition of data }\end{array}$ \\
\hline $\begin{array}{l}\text { W. Jeff Elias, } \\
\text { MD }\end{array}$ & $\begin{array}{l}\text { University of Virginia } \\
\text { School of Medicine, } \\
\text { Charlottesville }\end{array}$ & $\begin{array}{l}\text { Major role in the } \\
\text { acquisition of data }\end{array}$ \\
\hline $\begin{array}{l}\text { Piotr W. } \\
\text { Olejniczak, } \\
\text { MD, PhD }\end{array}$ & $\begin{array}{l}\text { Louisiana State University } \\
\text { Health Sciences Center, } \\
\text { New Orleans }\end{array}$ & $\begin{array}{l}\text { Major role in the } \\
\text { acquisition of data }\end{array}$ \\
\hline $\begin{array}{l}\text { Nicole R. } \\
\text { Villemarette- } \\
\text { Pittman, PhD }\end{array}$ & $\begin{array}{l}\text { Louisiana State University } \\
\text { Health Sciences Center, } \\
\text { New Orleans }\end{array}$ & $\begin{array}{l}\text { Major role in the } \\
\text { acquisition of data; } \\
\text { drafting/revising } \\
\text { manuscript for intellectual } \\
\text { content }\end{array}$ \\
\hline
\end{tabular}

\begin{tabular}{lll}
\hline $\begin{array}{l}\text { Stephan } \\
\text { Eisenschenk, } \\
\text { MD }\end{array}$ & $\begin{array}{l}\text { University of Florida, } \\
\text { Gainesville, }\end{array}$ & $\begin{array}{l}\text { Major role in the } \\
\text { acquisition of data }\end{array}$ \\
\hline $\begin{array}{l}\text { Steven N. } \\
\text { Roper, MD }\end{array}$ & $\begin{array}{l}\text { University of Florida, } \\
\text { Gainesville, }\end{array}$ & $\begin{array}{l}\text { Major role in the } \\
\text { acquisition of data; } \\
\text { drafting/revising } \\
\text { manuscript for intellectual } \\
\text { content }\end{array}$ \\
\end{tabular}

\begin{tabular}{|c|c|c|}
\hline $\begin{array}{l}\text { Jane G. } \\
\text { Boggs, MD }\end{array}$ & $\begin{array}{l}\text { Wake Forest University } \\
\text { Health Sciences, Winston- } \\
\text { Salem, NC }\end{array}$ & $\begin{array}{l}\text { Major role in the } \\
\text { acquisition of data }\end{array}$ \\
\hline $\begin{array}{l}\text { Tracy A. } \\
\text { Courtney, BS }\end{array}$ & $\begin{array}{l}\text { NeuroPace, Inc, Mountain } \\
\text { View, CA }\end{array}$ & $\begin{array}{l}\text { Design or } \\
\text { conceptualization of the } \\
\text { study; analysis or } \\
\text { interpretation of the data }\end{array}$ \\
\hline $\begin{array}{l}\text { Felice T. Sun, } \\
\text { PhD }\end{array}$ & $\begin{array}{l}\text { NeuroPace, Inc, Mountain } \\
\text { View, CA }\end{array}$ & $\begin{array}{l}\text { Design or } \\
\text { conceptualization of the } \\
\text { study; analysis or } \\
\text { interpretation } \\
\text { of the data }\end{array}$ \\
\hline $\begin{array}{l}\text { Cairn G. } \\
\text { Seale, MS }\end{array}$ & $\begin{array}{l}\text { NeuroPace, Inc, Mountain } \\
\text { View, CA }\end{array}$ & $\begin{array}{l}\text { Design or } \\
\text { conceptualization of the } \\
\text { study }\end{array}$ \\
\hline $\begin{array}{l}\text { Kathy L. } \\
\text { Miller, BS }\end{array}$ & $\begin{array}{l}\text { NeuroPace, Inc, Mountain } \\
\text { View, CA }\end{array}$ & $\begin{array}{l}\text { Analysis or interpretation } \\
\text { of the data }\end{array}$ \\
\hline $\begin{array}{l}\text { Tara L. } \\
\text { Skarpaas, } \\
\text { PhD }\end{array}$ & $\begin{array}{l}\text { NeuroPace, Inc, Mountain } \\
\text { View, CA }\end{array}$ & $\begin{array}{l}\text { Analysis or interpretation } \\
\text { of the data; drafting/ } \\
\text { revising manuscript for } \\
\text { intellectual content }\end{array}$ \\
\hline $\begin{array}{l}\text { Martha J. } \\
\text { Morrell, MD }\end{array}$ & $\begin{array}{l}\text { NeuroPace, Inc, Mountain } \\
\text { View, CA; Stanford } \\
\text { University, Palo Alto, CA }\end{array}$ & $\begin{array}{l}\text { Design or } \\
\text { conceptualization of the } \\
\text { study; analysis or } \\
\text { interpretation of the data; } \\
\text { drafting/revising } \\
\text { manuscript for intellectual } \\
\text { content }\end{array}$ \\
\hline
\end{tabular}


Appendix 2 Coinvestigators

Coinvestigators are listed at links.Iww.com/WNL/B153

\section{References}

1. Engel J Jr, Wiebe S, French J, et al. Practice parameter: temporal lobe and localized neocortical resections for epilepsy. Epilepsia 2003;44:741-751.

2. Shimamoto $\mathrm{S}, \mathrm{Wu} \mathrm{C}$, Sperling MR. Laser interstitial thermal therapy in drug-resistant epilepsy. Curr Opin Neurol 2019;32:237-245.

3. West S, Nolan SJ, Cotton J, et al. Surgery for epilepsy. Cochrane Database Syst Rev 2015; 7:CD010541.

4. DeGiorgio CM, Schachter SC, Handforth A, et al. Prospective long-term study of vagus nerve stimulation for the treatment of refractory seizures. Epilepsia 2000;41: 1195-1200.

5. Ramsay RE, Uthman BM, Augustinsson LE, et al. Vagus nerve stimulation for treatment of partial seizures, 2: safety, side effects, and tolerability: First International Vagus Nerve Stimulation Study Group. Epilepsia 1994;35:627-636.

6. Fisher R, Salanova V, Witt T, et al. Electrical stimulation of the anterior nucleus of thalamus for treatment of refractory epilepsy. Epilepsia 2010;51:899-908.

7. Salanova V, Witt T, Worth R, et al. Long-term efficacy and safety of thalamic stimulation for drug-resistant partial epilepsy. Neurology 2015;84:1017-1025.

8. Bergey GK, Morrell MJ, Mizrahi EM, et al. Long-term treatment with responsive brain stimulation in adults with refractory partial seizures. Neurology 2015;84: 810-817.

9. Heck CN, King-Stephens D, Massey AD, et al. Two-year seizure reduction in adults with medically intractable partial onset epilepsy treated with responsive neurostimulation: final results of the RNS System pivotal trial. Epilepsia 2014;55:432-441.

10. Morrell MJ. Responsive cortical stimulation for the treatment of medically intractable partial epilepsy. Neurology 2011;77:1295-1304.

11. Sun FT, Morrell MJ. The RNS System: responsive cortical stimulation for the treatment of refractory partial epilepsy. Expert Rev Med Devices 2014;11:563-572.

12. Devinsky O, Vickrey BG, Cramer J, et al. Development of the quality of life in epilepsy inventory. Epilepsia 1995;36:1089-1104.

13. Weber PB, Kapur R, Gwinn RP, Zimmerman RS, Courtney TA, Morrell MJ. Infection and erosion rates in trials of a cranially implanted neurostimulator do not increase with subsequent neurostimulator placements. Stereotact Funct Neurosurg 2017;95:325-329.

14. Wei Z, Gordon CR, Bergey GK, Sacks JM, Anderson WS. Implant site infection and bone flap osteomyelitis associated with the NeuroPace responsive neurostimulation system. World Neurosurg 2016;88:687.e1-687.e6.

15. Ryvlin P, Cucherat M, Rheims S. Risk of sudden unexpected death in epilepsy in patients given adjunctive antiepileptic treatment for refractory seizures: a metaanalysis of placebo-controlled randomised trials. Lancet Neurol 2011;10:961-968.

16. Loscher W, Schmidt D. Experimental and clinical evidence for loss of effect (tolerance) during prolonged treatment with antiepileptic drugs. Epilepsia 2006;47:1253-1284.

17. Hessen E, Lossius MI, Gjerstad L. Health concerns predicts poor quality of life in wellcontrolled epilepsy. Seizure 2009;18:487-491.

18. Loring DW, Meador KJ, Lee GP. Determinants of quality of life in epilepsy. Epilepsy Behav 2004;5:976-980.

19. Behrens E, Schramm J, Zentner J, Konig R. Surgical and neurological complications in a series of 708 epilepsy surgery procedures. Neurosurgery 1997;41:1-9.

20. Silberbusch MA, Rothman MI, Bergey GK, Zoarski GH, Zagardo MT. Subdural grid implantation for intracranial EEG recording: CT and MR appearance. AJNR Am J Neuroradiol 1998;19:1089-1093.

21. Wong $\mathrm{CH}$, Birkett J, Byth $\mathrm{K}$, et al. Risk factors for complications during intracranial electrode recording in presurgical evaluation of drug resistant partial epilepsy. Acta Neurochir (Wien) 2009;151:37-50.

22. Engel J Jr, Wiebe S, French J, et al. Practice parameter: temporal lobe and localized neocortical resections for epilepsy: report of the Quality Standards Subcommittee of the American Academy of Neurology, in association with the American Epilepsy
Society and the American Association of Neurological Surgeons. Neurology 2003;60 538-547.

23. Wiebe S, Blume WT, Girvin JP, Eliasziw M. A randomized, controlled trial of surgery for temporal-lobe epilepsy. N Engl J Med 2001;345:311-318.

24. Weaver FM, Follett K, Stern M, et al. Bilateral deep brain stimulation vs best medical therapy for patients with advanced Parkinson disease: a randomized controlled trial. JAMA 2009;301:63-73.

25. Shorvon S, Tomson T. Sudden unexpected death in epilepsy. Lancet 2011;378 2028-2038.

26. Dasheiff RM. Sudden unexpected death in epilepsy: a series from an epilepsy surgery program and speculation on the relationship to sudden cardiac death. J Clin Neurophysiol 1991;8:216-222.

27. Devinsky O, Friedman D, Duckrow RB, et al. Sudden unexpected death in epilepsy in patients treated with brain-responsive neurostimulation. Epilepsia 2018;59:555-561

28. Kahlow H, Olivecrona M. Complications of vagal nerve stimulation for drugresistant epilepsy: a single center longitudinal study of 143 patients. Seizure 2013;22:827-833.

29. Lambert MV, Robertson MM. Depression in epilepsy: etiology, phenomenology, and treatment. Epilepsia 1999;40(suppl 10):S21-S47.

30. Meador KJ, Kapur R, Loring DW, Kanner AM, Morrell MJ. Quality of life and mood in patients with medically intractable epilepsy treated with targeted responsive neurostimulation. Epilepsy Behav 2015;45:242-247.

31. Loring DW, Kapur R, Meador KJ, Morrell MJ. Differential neuropsychological outcomes following targeted responsive neurostimulation for partial-onset epilepsy. Epilepsia 2015;56:1836-1844.

32. Gleissner U, Helmstaedter C, Schramm J, Elger CE. Memory outcome after selective amygdalohippocampectomy: a study in 140 patients with temporal lobe epilepsy. Epilepsia 2002;43:87-95

33. Helmstaedter C, Kurthen M, Lux S, Reuber M, Elger CE. Chronic epilepsy and cognition: a longitudinal study in temporal lobe epilepsy. Ann Neurol 2003;54 425-432.

34. Donos C, Breier J, Friedman E, et al. Laser ablation for mesial temporal lobe epilepsy: surgical and cognitive outcomes with and without mesial temporal sclerosis. Epilepsia 2018;59:1421-1432.

35. RNS System User Manual (RNS-300M). Mountain View: NeuroPace, Inc; 2018

36. Sette AL, Seigneuret E, Reymond F, et al. Battery longevity of neurostimulators in Parkinson disease: a historic cohort study. Brain Stimul 2019;12:851-857.

37. DiLorenzo DJ, Mangubat EZ, Rossi MA, Byrne RW. Chronic unlimited recording electrocorticography-guided resective epilepsy surgery: technology-enabled enhanced fidelity in seizure focus localization with improved surgical efficacy. J Neurosurg 2014 120:1402-1414.

38. Enatsu R, Alexopoulos A, Bingaman W, Nair D. Complementary effect of surgical resection and responsive brain stimulation in the treatment of bitemporal lobe epilepsy: a case report. Epilepsy Behav 2012;24:513-516.

39. Ma BB, Rao VR. Responsive neurostimulation: candidates and considerations. Epilepsy Behav 2018;88:388-395.

40. Skarpaas TL, Tcheng TK, Morrell MJ. Clinical and electrocorticographic response to antiepileptic drugs in patients treated with responsive stimulation. Epilepsy Behav 2018;83:192-200

41. Mackow MJ, Krishnan B, Bingaman WE, Najm IM, Alexopoulos AV, Nair DR. In creased caffeine intake leads to worsening of electrocorticographic epileptiform discharges as recorded with a responsive neurostimulation device. Clin Neurophysiol 2016;127:2341-2342.

42. Arcot DS, Tcheng TK, Morrell MJ. Quantitative electrocorticographic biomarkers of clinical outcomes in mesial temporal lobe epileptic patients treated with the RNS system. Clin Neurophysiol 2019;130:1364-1374.

43. Kokkinos V, Sisterson ND, Wozny TA, Richardson RM. Association of closed-loop brain stimulation neurophysiological features with seizure control among patient with focal epilepsy. JAMA Neurol 2019;76:800-808.

44. Baud MO, Rao VR. Gauging seizure risk. Neurology 2018;91:967-973

45. Baud MO, Kleen JK, Mirro EA, et al. Multi-day rhythms modulate seizure risk in epilepsy. Nat Commun 2018;9:88. 


\section{Neurology}

\section{Nine-year prospective efficacy and safety of brain-responsive neurostimulation for focal epilepsy}

Dileep R. Nair, Kenneth D. Laxer, Peter B. Weber, et al.

Neurology 2020;95;e1244-e1256 Published Online before print July 20, 2020

DOI 10.1212/WNL.0000000000010154

This information is current as of July 20, 2020

\section{Updated Information \&} Services

References

Citations

Permissions \& Licensing

Reprints including high resolution figures, can be found at: http://n.neurology.org/content/95/9/e1244.full

This article cites 44 articles, 4 of which you can access for free at: http://n.neurology.org/content/95/9/e1244.full\#ref-list-1

This article has been cited by 5 HighWire-hosted articles: http://n.neurology.org/content/95/9/e1244.full\#\#otherarticles

Information about reproducing this article in parts (figures,tables) or in its entirety can be found online at:

http://www.neurology.org/about/about_the_journal\#permissions

Information about ordering reprints can be found online:

http://n.neurology.org/subscribers/advertise

Neurology ${ }^{\circledR}$ is the official journal of the American Academy of Neurology. Published continuously since 1951, it is now a weekly with 48 issues per year. Copyright Copyright ( 2020 The Author(s). Published by Wolters Kluwer Health, Inc. on behalf of the American Academy of Neurology.. All rights reserved. Print ISSN: 0028-3878. Online ISSN: 1526-632X.

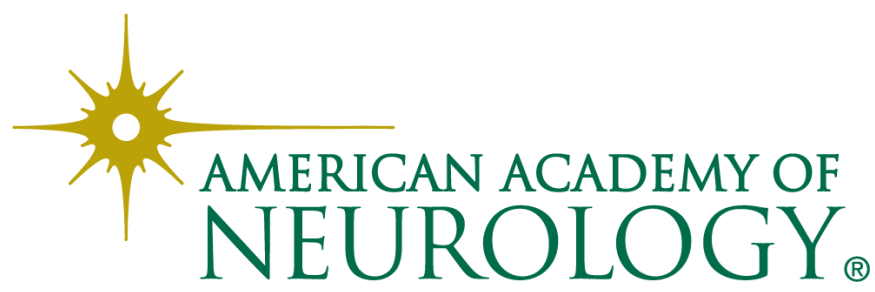

